ÉGYPTE monde arabe

\section{Égypte/Monde arabe}

33 | 1998

Travailleurs et industrie à l'heure des réformes

économiques

\title{
Working and living in 10th of Ramadan City
}

The Perspective of Workers in Small Industries

Jochen Möller

\section{OpenEdition \\ Journals}

Édition électronique

URL : https://journals.openedition.org/ema/1575

DOI : $10.4000 /$ ema. 1575

ISSN : 2090-7273

Éditeur

CEDEJ - Centre d'études et de documentation économiques juridiques et sociales

Édition imprimée

Date de publication : 30 juin 1998

Pagination : 67-80

ISSN : 1110-5097

Référence électronique

Jochen Möller, «Working and living in 10th of Ramadan City », Égypte/Monde arabe [En ligne], 33 |

1998, mis en ligne le 08 juillet 2008, consulté le 07 juillet 2022. URL : http://journals.openedition.org/ ema/1575; DOl : https://doi.org/10.4000/ema.1575

Ce document a été généré automatiquement le 7 juillet 2022

Tous droits réservés 


\title{
Working and living in 10th of Ramadan City
}

\author{
The Perspective of Workers in Small Industries
}

Jochen Möller

1 The decisive role of small industries in private sector development has been extensively discussed both at the official level and within economic studies. While small industries are seen as a major contributing factor in both economic and social development, some features of small industries appear particularly problematic. Many of these features directly affect workers : wages, implementation of workers' rights, work safety and social security. Moreover, training possibilities as means of developing human resources and environmental protection seem to remain unsatisfactory, especially when compared to bigger industries. In most cases, bigger industries offer, besides standard necessities (such as social security), additional advantages, providing flats, bonuses, recreational facilities and the like.

2 Similarly, the role of the "New Communities" in private sector development in Egypt has been underlined ever since late President Sadat's « October Paper» was published in 1974. However, while the private sector economy is booming in new cities like 10th of Ramadan City, it is widely felt that the goal of establishing these cities, as new avenues of settlement providing attractive alternatives to the traditional centres like the Cairo megalopole, has not been achieved.

In order to contribute to the discussion of these problems, a study group focusing on the issues of working and living conditions in the new cities conducted a study assessing the perspective of workers in small industry workshops. The project took place within the framework of the "ASA programme ", a scholarship program in the field of developmental studies under the umbrella of the German Carl-DuisbergGesellschaft. The field study was conducted in August 1997, under the auspices of the Federation of Egyptian Industries. The Friedrich Ebert Foundation introduced the study group to a partner for conducting the survey. The Association of Small Industrialists and Small Scale Industries in the New Cities (ASSINC), a small businessmen association based in 10th of Ramadan City, found the focus of the project fitting with a sub-aim of 
its agenda demanding that better working and living conditions be promoted in the new cities. Four fields of interest were defined: the worker's social background, the work environment in small industry workshops, certain aspects of social security and living conditions in 10th of Ramadan City.

4 Due to the practical approach suggested by ASSINC, the study group focused on small and medium-sized industry workshops owned by members of ASSINC and situated in the « $\mathrm{C} 2$ » small industry complex in 10th of Ramadan City. The businessmen were interested in results that could benefit their association by drafting proposals for new activities. Furthermore, the individual entrepreneurs were interested in an assessment of their workshops, especially as far as suggestions and needs expressed by the workers were concerned. A total of 104 workers in « $\mathrm{C} 2$ » were interviewed by the study group in a structured open dialogue. 40 additional interviews were carried out in other companies in both 10th of Ramadan and 6th of October City.

It should be underlined that the field work of the study group was neither statistically comprehensive nor accurately defined in terms of a representative sample of small industries. The 104 workers interviewed should be considered a random sample based on close cooperation with ASSINC and the practical approach of the study. The sample neither represents Egypt's small industry in general nor 10th of Ramadan City's small industry in particular.

6 The majority of the 14 companies in « $\mathrm{C} 2$ » cooperating with the study group employed up to 20 workers. Of these, most employed under 10 workers. Only 2 companies employed 50 to 100 workers and showed features of médium scale industries. The variety of workshops ranged from production of medical devices, Chemicals and plastic products to wood, furniture, textiles, salt, milk and soya products.

7 The study group lived in 10th of Ramadan City for a month, which allowed flexible field visits, sometimes during nightshifts, as well as personal contacts with workers through reciprocal invitations, football games, etc. The working language was Arabic. Workers were usually selected for interviews and presented to the group according to the procedure proposed by the individual workshop owner. This implied in some cases having the factory director sitting nearby, while in others, chatting in the relaxed setting of the C2 Complex cafeteria. Other interviews were conducted by chance, for example upon meeting a worker who had just decided to quit his job. The following article summarizes some of the main findings of the field study. The Friedrich Ebert Foundation will publish the results in early 1998. Comparisons with results of the study carried out in «C2 » by Alia El Mahdy and Hala El Said in 1996 will be drawn where appropriate and in the concluding section.

\section{Social profile of the sample}

With regard to the overall profile of the sample, some of our findings concur with those of Alia El Mahdy and Hala El Said.

The majority of the workers are male $(92 \%)$ and aged 20 to 30 years old. The average age of the male workers is 27 , whereas the average woman's age is 19 . The majority of women are single. Approximately $50 \%$ of the male workers are single, another $15 \%$ engaged. There are not many children under 15 years working in the cooperating 
enterprises, but some other workshops in « $\mathrm{C} 2$ » are known to rely intensively on child labour.

The level of education of the sample is relatively high. Almost $50 \%$ of the respondents hold at least one diploma, and $11,5 \%$ are university graduates. These figures indicate that factory directors and foremen tend to select « educated people » for interviews.

11 With regard to the workers' origin, we should underline that $71 \%$ were born in the Delta ; $51 \%$ in the Sharqiyya governorate alone, and only $16 \%$ in the Greater Cairo region. $55 \%$ of the workers reside outside 10th of Ramadan City, the majority living in Sharqiyya Governorate (36\%), followed by Cairo (10\%) and Qalyubiyya (9\%). A considerable number of workers do not live in 10th of Ramadan. Many of them share flats or stay in flats provided by the workshop owner.

12 We undertook to divide the respondents into skilled and unskilled workers. After each interview, an « informal assessment » was prepared by the interviewers. Professional vocational training, working for an extended timespan at the same workshop or for various companies in the same field are considered to build skills. For example, a worker may acquire skills through «training on the job» by working in the field of plastic products for several years. According to these criteria, the sample is composed of 49 skilled and 55 unskilled workers.

\section{Work environment}

13 Some workers did not answer the more sensitive questions related the work environment. This was partly due to caution, notably when the factory director was listening.

\section{Work stability}

14 To the question of whether they were bound by a contract, only 79 workers responded. Of these, $53 \%$ are employed upon the basis of a « spoken agreement ", another $10 \%$ have contracts regarded as probation time. Thus, only $37 \%$ of those answering the question have a written contract :

\begin{tabular}{|l|l|}
\hline Spoken agreement & $40 \%$ \\
\hline Probation Time & $8 \%$ \\
\hline Contract & $28 \%$ \\
\hline NA & $24 \%$ \\
\hline
\end{tabular}

$(100 \%=104)$

Questions related to the labour turnover were answered in ways too differentiated to quantify. The entrepreneurs stress that high labour turnover is one of their major problems : "Someone pays them a few extra pounds and they are gone.» Responses regarding the expected length of stay at the worshop read as follows (89 answers available from a total of 104): 


\begin{tabular}{|l|c|}
\hline I don't know, but want to stay & $34 \%$ \\
\hline I don't know, but want to leave & $26 \%$ \\
\hline I expect to stay around 6 months & $11 \%$ \\
\hline I expect to stay around 1 year & $11 \%$ \\
\hline I expect to stay around 2 years & $4 \%$ \\
\hline NA & $14 \%$ \\
\hline
\end{tabular}

16 The main reasons workers expressed for an expected end of employment at the workshop are « another job» or «family " (marriage, childbirth). When asked about factors that could attract them to another working place, most of the workers mentioned higher wages. As many as 33 workers stress that they would like to change to public sector employment as soon as possible. These workers are well aware of resulting disadvantages, especially low wages. Advantages mentioned mostly concern the stability of public sector employment and the social security provided. The majority of workers commenting on the advantages of the public sector do not expect a decline of its importance in Egypt. 37 respondents have already thought about starting up their own business. Some complain about the inaccessibility of credits, others already run a small « project » (mashrû), and one respondent is working in order to save enough money to start up his own business. Conversely, some workers expressed the hope that they may "grow with the workshop" that employs them. Many workers depict the instability and insecurity prevailing in a number of workshops. According to them, workers come and go depending on the economic situation of the company. Some workers even state that every 6 months the workforce changes entirely.

\section{Wages}

17 There are obvious problems in defining exact wages through interviews. Both employer and employee tend to understate these sums, as taxes and contributions to social security are based upon them. Sometimes, overtime and extra payments are not mentioned even though (or because) some workers may work overtime every day. Nevertheless, the wage average based on the findings of the ASA study group is considerably higher than the one found by El Mahdy and El Said in 1996.

Findings of the study suggest an average wage of 273 Egyptian pounds (£e) monthly. The difference between wages of skilled and unskilled workers as defined in the course of the study should be taken into account : skilled workers earn an average of £e 357 monthly, whereas unskilled workers earn £e 170.

\section{Working hours}

We found a variety of procedures related to working hours. One problem in defining working hours stems from the fact that overtime is often understood as being an integral part of working hours. Thus, some workers may officially work 8 hours, but in 
fact work for another 4 hours daily. Even without these overtime hours, their wages might be insufficient. If transport for the non-resident is provided free of charge by a company after 12 working hours, workers have an even bigger interest in this regular overtime work.

The average work day consists in approximately 10 hours. In one extraordinary case, 8 of the respondents work 24 hours non-stop and are granted a free day afterwards. They all describe this as being extremely tiring.

\section{Nature of work}

The majority of workers claim they receive their working instructions from foremen or factory directors. The direct involvement of the entrepreneur in production, a feature often attributed to small industries, does not seem to apply in the « $\mathrm{C} 2$ » companies visited. As found during the study, sensitive questions related to work security and environmental pollution often prompt caution or are not understood by the workers. A more pragmatic approach to obtain workers' ideas about their work environment was to put an open question to the respondents regarding their ideas about what could be changed or amended at their work place. After structuring the answers, the results read as follows :

\begin{tabular}{|l|l|}
\hline Management & $23 \%$ \\
\hline Working Conditions & $22 \%$ \\
\hline Workers' Situation & $16 \%$ \\
\hline Social Security & $39 \%$ \\
\hline
\end{tabular}

As far as management is concerned, most suggestions centered around wishes for a better flow of communication between entrepreneur and workers and encouragement of workers' initiative and responsibility.

The main suggestions regarding working conditions aim at enhancing work security and health care. In many cases, better air circulation or air exhaust are demanded. Another point frequently brought up is the lack of a special time or a room designated for recess. The workers' situation is generally assessed as being very weak, especially with the absence of unions. They demand more guarantees of their rights and less pressure from management. The workers suggest that rules concerning work should be explicitly noted and wish to be better informed about their rights. They hope that initiatives towards increasing social security will be undertaken by their employers.

\section{Aspects of Social Security}

Our main questions on the topic of social security were « Are you insured? » and «Is your monthly wage enough to cover all living expenses?»The study group gathered further statements and comments from the workers and focused on the problem of risk 
prevention and compensation : "In cases of special expenses, cases of emergency and the like, who or what could help you?» In this context, workers were asked to give concrete examples.

\section{Insurance}

In direct contrast to El Mahdy's findings (1996) where most workers benefited from Social Insurance, we found that the majority of respondents were insured in 1997. 49 workers, i.e. $57 \%$ of the sample answering the question (86 answers available) state that they are not insured. 8 persons out of the 37 workers who are insured lack Health Insurance. Some workers accept this as they expect to stay at the workshop only for a limited time. Some workers underline their lack of trust in the formal Social Insurance system : «I have no money to spare for this. » Other workers, however, criticize the situation and blame the entrepreneur. When asked about amendments that should be brought about at their work place, $39 \%$ of suggestions concentrate on implementing social security measures. The majority of these suggestions aim at establishing a Trust Fund as a privately organized alternative to the official Social Insurance system.

\section{Living expenses}

When asked about the cost of living, $40 \%$ of the workers stress that they do not earn a sufficient amount of money to cover their monthly living expenses. Another $27 \%$ say they could only scarcely « make a living ». $37 \%$ of the workers claim they have a second job. In several cases, the second source of income of the workers comes from owning a small workshop, while others continue to work as farmers.

This leads us to conclude that a considerable amount of the interviewed workers are "working poor» whose situation will not change through working in the small industry. Considering also the fact that workers are often not insured by their employer, a question arises as to how the workers can cope financially with extraordinary and critical situations.

\section{Extraordinary and critical situations}

When asked about who or what could support them in critical situations, around $10 \%$ of the workers state that there is no one to help them. The possibility of obtaining credit from the employer is suggested by as many as $37 \%$, followed by the help expected from the family ( $32 \%) .14 \%$ of the respondents suggest setting up a Savings Club (gam'iyya). Other resources such as a Trust Fund, friends or overtime work play only a minor role. Illnesses and accidents rank first in a list of concrete examples for critical situations given by workers : in around one third of the cases, these have caused a worker a difficult situation. $21 \%$ of concrete problems mentioned are caused by the immense cost of marriage or engagement. Another $21 \%$ ot the cases are due to general lack of income, and $16 \%$ refer to urgently needed money. Divorce and childbirth are also mentioned (5 \% each).

With regard to the help obtained in the above mentioned examples, it must be underlined that the role of family support in such costly situations is decisive : in $47 \%$ of the cases, the workers are helped by their family. Credit from the entrepreneur is a 
solution in $32 \%$ of the cases. This usually means that the sum obtained is paid back by monthly wage deductions. Other sources of help include donations, neighbours, a Trust Fund or a Savings Club (each $5 \%$ ).

Thus, we may conclude that instruments other than traditional family solidarity and the possibility of getting a loan from the employer are rarely used. Workers' statements on experiences such as these stress the normality and acceptability of mutual help among family members. Obtaining a loan from the employer is also a widely accepted means of solving financial problems, but many respondents stated that a monthly cut in wages causes other problems and that paying back such a loan can therefore be difficult. Clearly, offering a loan can be used as a means of tying workers to their workshop.

\section{Example of a privately organized instrument : the Trust Fund}

A Trust Fund is established by workers' mutual agreement upon a slight cut in monthly wages with the aim of directing sums to the participants on certain occasions.

There was only one example of such a Fund mentioned in the sample of 10th of Ramadan City's « C2 » complex. 8 workers mentionned the possibility of obtaining fe 200 in the event of either marriage or a close relative's death. This sum comes from the Trust Fund administered by the accounting department of a company. $2 \%$ of each worker's salary is automatically directed to this Fund monthly.

Two workers complained that there may be many other occasions when a payment from the Fund should be forthcoming, for example in cases related to illness. There are, however, no complaints regarding the time table for the payment of the £e 200 . Another advantage of the Fund is that all workers may equally benefit from it, regardless of their status (contract, probation time, no contract) within the factory.

During the course of the study, we were surprised to find that the Trust Fund idea seemed to be of more common knowledge amongst workers than amongst the small entrepreneurs. This may be due to previous experiences workers had at other (bigger ?) companies. Workers also pointed out that they usually discuss and compare wages and other benefits when meeting workers from other companies, for example when travelling from their hometown to 10th of Ramadan City. The workers' knowledge of Trust Fund systems coincides with the willingness of the majority to contribute to such a Fund.

\section{0th of Ramadan City}

10th of Ramadan City, located on the desert route between Cairo and Ismâ'îliyya, has good connections to the Eastern delta. Its vast empty roads and the buildings built in orderly squares are striking. The construction of the City was originally supposed to involve private investors and the Council of City Development. In later stages, however, the Council started to build whole quarters, especially for lower income groups. Today, vast desert areas, intended for buildings and mostly sold to private investors, are lying unused between four-track roads with a strip of greenery in between. This halfcompleted look characterizes all but the oldest quarters of 10th of Ramadan City. In contrast to these, where a diversity of housing styles prevails, the newer parts consist 
of mostly five-storey buildings intended for workers who can rent or buy a flat. These are lively quarters, as a large part of the working population of 10th of Ramadan City is residing there of late. In the older quarters, main houses and flats are empty. Owners wait for more profitable clients, such as entrepreneurs or foreigners working for a limited time in 10th of Ramadan City. Also, many inhabitants of villas spend most of the year in Cairo or other places. Lately, the Council of City Development has given preference to buyers or tenants working in 10th of Ramadan City in order to prevent speculation on land and housing.

10th of Ramadan City has nothing less than the atmosphere of a traditionally grown Oriental city with its narrow streets and lanes. This otherwise appreciated atmosphere of modernity was rejected by some of the respondents as uncomfortable.

\section{0th of Ramadan City as seen by commuting workers}

Most of the workers interviewed reside in the Delta region or the Greater Cairo area. One of the main problems they expressed is the time and effort spent on their way to work and back. In extreme cases, workers commuted up to 7 hours daily, actually spending one third of their wages on transportation. The majority of commuting workers daily spend on average two hours on transport. Most of them consider the circumstances of commuting as being tiring and having a negative impact on their work performance. This may result in many small accidents inside the workshops (cuts, bruises).

However, when asked about the possibility of moving to 10th of Ramadan City to put an end to these problems, the majority of workers reject the idea. The main reasons given are existing social relations, family ties and responsibilities, and the feeling of being bound to their hometown. The modernity of 10th of Ramadan City seems to enhance feelings of alienation for people coming from a traditional rural background.

A main argument for workers against settling in 10th of Ramadan City is the high cost of flats and living. Food prices in 10th of Ramadan City are indeed considerably higher than in the Delta. Concerning the purchase of a flat, workers may get a special bank loan, but an initial amount of £e 4000-6000 is required upfront, followed by monthly payments comparable to a rent, which often require the financial aid of the whole family. As shown above, wages earned by working in 10th of Ramadan City's industries are not always sufficient to cover a worker's monthly expenses. The lack of informal job possibilities, due to the newness of the city and the policy of the Council of City Development, might explain the workers' unwillingness to move to 10th of Ramadan City and to take the risk of depending solely on « formal » income generation.

Related to this is the workers' assessment of their job stability. Many of the respondents do not intend or expect to work at their present workshop for an extended timespan. Reasons given for this include the wish for another (usually more lucrative) job or personal reasons (marriage, childbirth, family in general). Most of the workers feel that they have no guarantee of job stability from their employer. For them, a job in the private sector industry automatically implies lack of job stability. Many small-scale industry workshops function through the labour of unskilled and trained-on-the-job workers, because it is more practical («All are more or less unskilled») or due to financial reasons (wages of unskilled labour being considerably lower). Most of these unskilled workers are constantly looking for possibilities of further advancement, be it 
an increase in wages or the opportunity to improve skills. Often having no real incentive tying them to their present workplace, they are ready to leave it as soon as the possibility to obtain higher wages arises.

In relation to the development of 10th of Ramadan City, the most important incentive to settle would be the opportunity to obtain cheap housing through help offered by the employer. At present, this option is offered only to workers who are considered essential for the workshop by their employer, such as foremen and engineers.

The average amount of money a worker's family could afford to pay for a flat was estimated by the master plan to be one fifth of the family's income. However, this does not seem to be a realistic estimate. Taking into account the average income of an unskilled worker (findings of the study : £e 170 monthly), this would mean a monthly charge of £e 34. Although one has to take into consideration that these calculations are based on a plan made 20 years ago, the difference between £e 34 and £e 88 (respectively, the average amount of rent and of monthly installments on a purchase, as found in the study) is quite significant with a monthly income as low as the above mentioned and can well tip the balance against a decision to move to 10th of Ramadan City.

44 Another strongly felt reason for not wanting to live in 10th of Ramadan City is the scarce social relations of most workers in the city which not only includes a personal feeling of loneliness, but could also build into a major obstacle in starting up a life in a New City. Indeed, members of the lower income strata in Egypt live not only on their income, but often work on a second job or have family members contributing to the family income, often in the informal sector. Also, mutual help among neighbours and friends, which often includes financial aid, ranges high on the scale of social relations displayed in the traditional way of life in rural areas. New Cities like 10th of Ramadan City lack these advantages. Here, families mostly have to rely on «formal " income alone. Considering the feeling of job insecurity the workers expressed, settling in the New City may appear fraught with risks.

\section{0th of Ramadan City as seen by workers living there}

45 The public housing policy in 10th of Ramadan City concentrated on building houses for the lower income strata, in order to create attractive housing possibilities for workers employed in the city's industrial sites. However, by the end of the eighties only one third of available flats had been purchased. Although prices were then considerably lower than the prices for flats in Cairo, this did not incite workers to settle in 10th of Ramadan City. Since then, high inflation rates forced the government to increase the prices of flats in 10th of Ramadan City, a move which further complicated efforts to attract more people to the city.

Less than half of the respondents actually reside in 10th of Ramadan City. More than $50 \%$ of these workers share flats or stay in « resthouses » - flats provided by their employer (istiraha). Some even live in the factory where they work. Those living in 10th of Ramadan City without family members and/or spouse consider their dwelling a mere "work residence ", as their social activities concentrate on their original hometown, where they return every weekend. The workers often state their intent to return « home » if they find work there. The cost of living in 10th of Ramadan City is generally considered high by the residents. For example, monthly payments for 
housing range from £e 30 for tenants of a shared flat to £e 133 for rented flats. Flat owners pay around £e 80 monthly as installments on a purchase-loan. The usual way to get a flat is to apply to the Council of City Development. A flat will be assigned almost immediately, as many are available in the City.

Most of the residents stress the fact that the City is quiet, well-ordered and enjoys a healthy climate. This is recognized as being the most positive aspect of living in 10th of Ramadan City. On the other hand, long-term residents stress the slowness of urban development, and, although they readily admit improvements in the infrastructure of the city, the main reason they state for this slowness is the relative underpopulation of 10th of Ramadan City. Accordingly, most hold that the City would improve rapidly if there were more inhabitants. Asked about the decisive factor promoting this goal, cheaper housing facilities are mentioned.

The most problematic issues mentioned about everyday life in 10th of Ramadan City are the high prices for food and insufficient supply of general items. As far as food is concerned, the agricultural background of most of the working residents in 10th of Ramadan City may explain this complaint. Being raised in a rural environment where most of the foodstuffs are grown locally, the prices of vegetables transported to 10th of Ramadan City seem expensive to them. In order to improve the quality of food, some of the residents mention independant initiatives such as baking their own bread or growing vegetables on a small scale in their own garden. Inner-city transportation is also a problem. Whereas the connections between the central bus station and the big industrial site " 3 " are quite good (although expensive in relation to the distances covered), smaller zones such as « $\mathrm{C} 2$ » can only be reached by foot or motorcycle. One fifth of the residents report problems regarding the commute to work. The majority of the 10th of Ramadan City residents interviewed live in one quarter. This is within walking distance of their workplace, but the walk takes up to 45 minutes and can be very tiring in hot weather. Lack of recreational facilities is the third most mentioned negative aspect of living in 10th of Ramadan City. While one fifth of the surveyed workers know of none at all, another fifth consider them inaccessible due to high costs (clubs) or the distance from their home. Plans by the City Council to build youth centers and other community facilities in each quarter had not yet been implemented.

\section{Conclusion}

« Whether the work setting welcomes him and provides him with security, stability and encouragement or not, remains to be investigated »(El Mahdy-El Said, 1996, p. 35). The field work undertaken by the ASA study group in 1997 aimed at assessing the workers' perspectives and provides initial contributions to the question raised by El Mahdy-El Said. Based on findings that differ considerably from El Mahdy-El Said's results concerning work stability and social security, we can state that the majority of workers seem to be in an insecure situation, depending heavily on their employer. Many of them have to be considered "working poor ", remaining dependent on other sources of income. Wages earned may be comparatively attractive, especially for workers of rural origin, but nevertheless often seem insufficient to make a living. This leads many 
workers to accept any other job as soon as it is offered, even in the public sector economy, and preferably not in 10th of Ramadan City, since :

1. 10th of Ramadan City poses a number of specific problems (transportation, housing, cost of living, etc.) ;

2. in contrast to 10th of Ramadan City, the worker's hometown still offers a variety of advantages : traditional frameworks providing easily accessible, mutual help and chances for informal income generation for the workers or other family members ;

3. many workers feel insecure about job stability, and consequently look for alternatives.

50 From the perspective of quite a number of workers, working in 10th of Ramadan City seems to serve as a means of « saving money", for example before marriage and resettling in their original place of residence once a job opportunity arises there. Furthermore, there is a clear division between skilled and unskilled workers. The skilled or experienced workers are important to the flow of production; consequently, they are in a strong position and seem to benefit from several advantages. On the other hand, the unskilled or newly employed workers are not in a position to negotiate, resorting to this high labour turnover workshop owners complain about.

51 The picture drawn from interviews based on a random sample may serve as a first step towards developing new ideas and drafting new activity proposals. According to the businessmen of the ASSINC, lack of work stability and other negative features stressed by workers have a negative impact on productivity. This explains ASSINC's remarkable support for the study and gives hope that a businessmen pressure group might stipulate goals it shares with the small industry's workforce. Such goals may include new means of organizing training for the workforce of « $\mathrm{C} 2$ » and negotiating more favorable conditions for workers residing in 10th of Ramadan City, for example improving transport services. Providing incentives or help to those willing to settle in 10th of Ramadan City could be a means of tying workers to their job. As far as social security is concerned, the idea of establishing a Trust Fund seems to be attractive for both workers and employers. A positive example of an effective Trust Fund can be found among ASSINC-member companies, thus further joint discussion and organization of such privately-organized social security schemes may prove successful in the future.

\section{NOTES}

1. Alia El Mahdy et Hala El Said, 1996, Small Industry Complex in the 10th of Ramadan City: Needsand Potentials. A Target Group Analysis, Friedrich Ebert Stiftung, Cairo. Mentions of this study throughout the article will be made by simple reference to its authors. 
INDEX

Mots-clés : classe ouvrière, économie, villes nouvelles 